\title{
An Introduction to International Varieties of English
}

Laurie Bauer 
(C) Laurie Bauer, 2002

Edinburgh University Press Ltd 22 George Square, Edinburgh

Typeset in Janson

by Norman Tilley Graphics and printed and bound in Great Britain

by MPG Books Ltd, Bodmin, Cornwall

A CIP record for this book is available from the British Library

ISBN 0748613374 (hardback)

ISBN 0748613382 (paperback)

The right of Laurie Bauer

to be identified as author of this work

has been asserted in accordance with

the Copyright, Designs and Patents Act 1988. 